\title{
Increased taxation on cigarettes in Grenada: potential effects on consumption and revenue
}

\author{
Althea La Foucade, ${ }^{1}$ Samuel Gabriel, ${ }^{1}$ Ewan Scott, ${ }^{2}$ Charmaine Metivier, ${ }^{1}$ \\ Karl Theodore, ${ }^{1}$ Anton Cumberbatch, ${ }^{1}$ T. Alafia Samuels, ${ }^{3}$ Nigel Unwin, ${ }^{3}$ \\ Christine Laptiste, ${ }^{1}$ and Stanley Lalta ${ }^{1}$
}

Suggested citation La Foucade A, Gabriel S, Scott E, Metivier C, Theodore K, Cumberbatch A, et al. Increased taxation on cigarettes in Grenada: potential effects on consumption and revenue. Rev Panam Salud Publica. 2018;42:e195. https://doi.org/10.26633/RPSP.2018.195

\begin{abstract}
Objective. To investigate the feasibility of addressing the public health concerns of tobacco consumption through increased taxation, while preserving or augmenting government revenues in Grenada.

Methods. Purposive sampling methods were used to ensure data availability and geographical representativeness. Average price per 20-pack of the most-sold brands of cigarettes was calculated using data from three major supermarkets. The World Health Organization's Tax Simulation Model was used, with excise tax rates adjusted to effect 5\%,10\%, and 15\% consumption decreases.

Results. A $17 \%$ to $117 \%$ excise tax increase on the cost, insurance, and freight (CIF) value would achieve a 5\% consumption decrease. Total government revenues would grow $8.7 \%$ and excise tax revenues would increase $11 \%$. The average excise tax per 20-pack would move from EC\$ 3.24 (2014 US\$1.20) to EC\$3.80 (US\$ 1.41), while the average price per pack would increase to EC\$ 9.21 (US\$3.41) from EC\$8.48 (US\$3.14). In the $10 \%$ and $15 \%$ consumption reduction scenarios, excise taxes would have to be increased by 33\% and 50\% (to $133 \%$ and $150 \%$ of CIF, respectively), pushing the average excise tax per pack to EC\$4.37 (US\$1.62) and EC\$ 4.90 (US\$1.81), respectively.

Conclusion. In Grenada, consumption can be reduced alongside growth in government revenues, making available additional resources for health. This aligns with the literature, which indicates that taxation can be effective in pursuing the public health objective of reduced incidence of smoking-related illnesses via reduced consumption.
\end{abstract}

Keywords Taxation of the tobacco-derived products; legislation as topic; noncommunicable diseases, prevention \& control; Grenada; Caribbean Region.

HEU, Centre for Health Economics, The University of the West Indies, St. Augustine, Trinidad and Tobago. Send correspondence to Charmaine Metivier, Charmaine.Metivier@sta. uwi.edu

Department of Economics, The University of the West Indies, St. Augustine, Trinidad and Tobago.

3 George Alleyne Chronic Disease Research Centre, The University of the West Indies, Bridgetown, Barbados.
Statistics from the World Health Organization (WHO) indicate that while smoking prevalence has been decreasing in high-income countries, it has been trending upwards in developing countries. Globally, over $80 \%$ of smokers reside in low- and middle-income countries (1). According to the World Bank, Grenada, an island state located between the
Caribbean Sea and Atlantic Ocean (12 07 $\mathrm{N}, 6140 \mathrm{~W})$, is an upper-middle income country (2). It has a population of 111219 and its main foreign exchange earner is tourism. Grenada is also the world's second largest producer of nutmeg, earning the nickname "Spice Isle." The country has a Westminster style of government, with a bicameral Parliament consisting 
of a Senate and a House of Representatives. It is a Member State of Caribbean Community (CARICOM) and the Organization of Eastern Caribbean States (3). Like many of its Caribbean neighbors, Grenada's health system is funded mainly through general government revenues.

This paper investigates the possibility of addressing the public health concerns of tobacco consumption through increased taxation, without compromising government revenues in Grenada. During 2015 - 2017, cigarette imports fell steadily in Grenada, declining 25\% in 2016 from its 2015 level of 89.31 million sticks, and another $8 \%$ in 2017 to 61.1 million sticks $(3-5)$. The data show that most $(94 \%)$ of Grenada's cigarette imports originated from neighboring Trinidad and Tobago, the leading supplier of cigarettes in the Caribbean (5).

Given this context, it is important to continue control and prevention efforts in Grenada in order to reduce the burden of tobacco-linked diseases and to further curb the demand for cigarettes. Analyzing consumer behavior and the nature of the demand for tobacco products provides valuable information to economists, public health practitioners, policymakers, and other interested parties. The estimates produced by such analyses are critical to evaluating alternative policy approaches aimed at addressing the social and economic impacts of this unique consumer good. In particular, there is great interest in consumer response to price changes (price elasticity of demand) and the subsequent impacts that changing tax rates have on government revenue. Others, especially in the public health arena, tend to be more concerned with how the tax changes and other policies may affect the quantity of the good consumed. In general, tobacco taxes have aimed to raise revenue for the State. However, concerns about the health, social, and economic effects of tobacco consumption have been primary issues for the public health policy debate.

As of 2011, the WHO Framework Convention on Tobacco Control (FCTC) has been ratified by 14 of the 15 CARICOM Member States. It requires countries to act to reduce tobacco consumption through taxation, graphic warnings, banning smoking in public spaces, and banning promotion, sponsorship, and advertising (7). The FCTC has guided and prompted governments to act to restrict the sale and reduce the consumption of these tobacco products, in order to minimize the negative impact of consumption. Increased taxation is among the most common tools used to decrease tobacco usage. Some policymakers however, are concerned about the implications that higher taxes might have on generating tobacco-related government revenues.

\section{Literature review}

Price elasticity of demand plays a critical role in evaluating the potential tax revenue generated by a tobacco tax hike, as well as its influence on consumption. The larger the absolute value of the price elasticity of demand, the greater the impact on consumption and government revenues, ceteris paribus $(7-10)$. Several studies have produced varied results on the price elasticity of tobacco demand. Most of these, however, have found that consumers are relatively unresponsive to tobacco price changes, due in part to its addictive nature. In China, researchers (12) found that the price elasticity of demand for cigarettes ranged from -0.40 to -0.70 , while in the United States of America estimates ranged from -0.61 (13) to -0.22 (6) and in low- and middle-income countries, -0.2 to -0.8 (14). Research has shown that price increases affect both smoking prevalence and intensity (14).

Throughout the literature, many different methods have been used to assess the impact of increased tobacco taxes on cigarette consumption and government revenues. For the most part, the general conclusion has been that it is possible to simultaneously reduce consumption while raising additional tax revenues. In Indonesia, it was discovered that a $57 \%$ increase in the tobacco excise tax would bolster government revenues by $58 \%$ and reduce consumption by $18 \%$ (15). Moreover, a simulation model developed for low-income and middle-income countries predicted that an excise tax increase of $20 \%$ would result in a $14 \%$ increase in revenues and a 5\% reduction in cigarette consumption (16). In Jamaica, it was shown that a $25 \%$ increase in cigarette taxes would result in $16 \%$ growth for government revenue (8). Indeed, generating additional government revenues (possibly for investing in health), at least in the short- to medium-term, is a frequent outcome of higher taxes on tobacco products.

What is more, applying taxes to certain goods/services is sometimes believed to distort the workings of the free market system. Such tax measures force consumers and producers to alter their consumption and production choices, respectively. However, there may be circumstances where such interventions are justified, and economists generally identify a few such instances. One of these is when the good/service in question produces a social cost or benefit that is not reflected in its market price. In such cases, the good/service will either be over or under-produced $(12,16)$. Specifically, the existence of negative externalities (social costs) provides justification for taxing tobacco. Cordes and colleagues (13) have noted that whereas income and general excise taxes "drive a wedge between private and social costs and returns," taxing tobacco..."may bring private and social costs and returns into closer alignment with market prices to reflect more fully the external costs of smoking...." In pursuit of this end, an excise tax on tobacco comes highly recommended because it tends to be passed onto the consumer and requires relatively little administrative effort $(17-19)$.

Additionally, the social implications of addiction, including nicotine addiction, are widespread and affect family, community, employment, education, law and order, and other areas. While fiscal policy remedies geared towards tobacco addiction are likely to yield muted returns in the case of the addict, social utility and behavior modification programs and policies serve as effective deterrents to potential new smokers, who are largely youths. Often youth initiate smoking in response to peer-pressure, social conditioning, or as a means of stress relief. However, smoking as an outlet becomes less likely as cigarette prices rise, thereby providing an additional apologia for tobacco taxation as a consumption deterrent.

\section{MATERIALS AND METHODS}

This study employed a mixed-methods research design. Data were gathered through telephone and face-to-face interviews with 16 key informants. Additionally, formal written data were requested for several variables, including the tax structures, rates, prices, and sales volumes 
of cigarettes. Responses were received from the Ministry of Finance, Central Statistical Office, Customs and Excise Department, and some local retailers in Grenada. The mixed-methods design allowed for the triangulation of the data.

Since data on total cigarette sales were not readily available, Customs and Excise data, together with sales data collected from supermarkets were used. Given that all cigarettes sold in Grenada are imported, Customs and Excise data on imports of the product represented a very good proxy for domestic sales, which in turn served as a proxy for domestic consumption, assuming minimal re-exporting of the product.

The average price per pack of 20 for the most-sold brands of cigarettes was calculated based on data collected from three of the five major supermarkets on the island. A purposive sampling process was employed to ensure that the selected supermarkets stored the necessary data and that they were located in the north of the island, the south of the island, and the capital city, which is where the most price variation was expected. Monthly pricing data for January - December 2014 were collected from each of the three supermarkets and were used to calculate the average price per pack for the most-sold brands.

\section{TaXSiM methodology}

The WHO Tobacco Tax Simulation Model (TaXSiM), based on Microsoft Excel $^{\mathrm{TM}}$ (Microsoft Corp., Redmond, Washington, United States), was used to estimate the quantities of interest; that is, the potential to raise revenue from tobacco and the degree to which consumption would be affected by the tax. This method was chosen primarily because of its relatively low data requirements and its ability to effectively provide feasible estimates of the quantities of interest. The model requires a clear understanding of the types of taxes and tax bases that exist in the country of interest. The model assumes the final retail price $\left(P_{R}\right)$ is made up of three main components; the producer price $\left(P_{p}\right)$, the supply chain margin $\left(R_{M}\right)$ and the tax $(T)$, where:

$$
P_{R}=P_{p}+R_{M}+T
$$

The model separates each brand of the product into market segments based on price. The general segments assumed here are Premium, Medium, and Low.
Average retail price ${ }^{4}\left(\bar{P}_{R_{K}}\right)$ and average excise unit price $\left(\bar{E}_{k}\right)$ for each brand segment $(K)$ are calculated as follows:

$\bar{P}_{P_{k}}=\frac{\sum_{\theta=1}^{n} P_{R_{k}} Q_{k \theta}}{\sum_{\theta=1}^{n} Q_{k \theta}}$ and $\bar{E}_{k}=\frac{\sum_{\theta=1}^{n} E_{k \theta} \times Q_{k \theta}}{\sum_{\theta=1}^{n} Q_{k \theta}}$

where $Q k \theta$ is the sales quantity of brand $(\theta)$ in segment $(k)$ and $k=1,2,3$. Likewise, total excise revenues, total sales, and total tax revenues are calculated as:

$E R=\sum_{\theta=1}^{n} E X Q_{\theta}, T Q=\sum_{\theta=1}^{n} Q_{\theta}, T R=\sum_{\theta=1}^{n} T X Q_{\theta}$

where ER stands for total excise revenue, $T Q$ is the total quantity of cigarettes sold, $T$ is total tax value per unit, and TR is total tax revenue (excise tax, Value-Added Tax [VAT], import duties, and customs services charges).

When conducting the impact analysis of tax policies, the TaXSiM initially constructs a description of the existing market and tax situation for cigarettes at a comprehensive level, by brand and market segment. This creates a baseline against which the impact of different taxation strategies on key market parameters (consumer prices, consumption volumes, tax revenue, etc.) can be measured.

The model performs the analysis on the following assumptions:

1. Price-elasticity: that smokers of premium brands have a price-elasticity similar to that of smokers in high-income countries (also assuming individuals with higher income smoke premium brands) at $\mu_{k_{1}}=-0.2$ to -0.4 ; while smokers of economy brands (low) have a price-elasticity similar to that of low-income countries at $\mu_{k_{3}}=-0.8$ to -1.0 ; and smokers of midprice brands have a price elasticity that is an average of the two other groups at $\mu_{k_{2}}=-0.5$ to -0.7 .

2. Tax pass-through: that tax increases are eventually completely reflected in the final price of the product, consumers' price $\left(P_{R}\right)$.

3. Trading-down by smokers: that as prices increase, some smokers will reduce their average daily intake of their favorite brand and others may cease the practice altogether, but it is more plausible that many choose to

\footnotetext{
4 Since the prices entered are already averages, these calculated values for average retail price would be an average of the average-the grand mean.
}

"trade-down" to lower priced cigarettes, reflecting the cross-price elasticity of demand for product brands.

4. Illicit trade and tax revenue: that although there is concern of heavier taxes prompting smuggling and illicit trade (and consequently, reduced tax revenues), the TaXSiM implicitly addresses the possibility. Details of this, and other features of the model can be found in its methodology document (21).

\section{TaXSiM simulations}

In order to conduct the simulations, data on the characteristics of the initial tax system were entered into the model. The data include tax rates and base by types (Excise, VAT, etc.), estimates of price elasticity of demand for each brand segment, sales volumes, and final consumer prices for each product by brand. In this instance, only packs of 20 cigarettes were used in the analysis. Based on the data entered at this stage, the TaXSiM estimates initial (baseline) values for a number of variables of interest, including average excise tax per unit, average price per unit, sale volumes (consumption), total tax revenues, and excise tax revenues by brand segments. The researcher can then apply changes to the tax rates, base, or type, after which the model predicts how these changes will affect the variables of interest listed above. In practice, the simulations were conducted such that the excise tax rate was increased to produce a 5\%,10\%, and $15 \%$ fall in consumption. The predicted impact on total revenue and excise revenues, among other variables, was then analyzed.

\section{RESULTS}

Grenada's tax system is relatively simple and comprises four main taxes that have applicability to tobacco:

- Customs Service Charge (CSC)-a $6 \%$ CSC is payable on all imported goods;

- Customs Duties - applied to all goods imported from non-CARICOM Member States, levied at a rate of $35 \%$ of Cost, Insurance, and Freight (CIF) value;

- Excise Taxes-compounded on the customs duties and CSC (the rate was 95\% in 2014); and

- Value Added Tax (VAT) - $15 \%$ payable on most goods, including cigarettes. 
The 2014 sales data gathered from the sample of supermarkets indicated that the smokers in Grenada have several brands of cigarettes from which to choose, including Dunhill, Marlboro, Pall Mall, and Du Maurier, among others. The Dunhill Brand of cigarettes was the most-sold brand on the island, accounting for approximately $30 \%$ of sales, followed by Du Maurier (23\%). Based on Customs revenue collected for 2014, three of the most-sold brands were selected, representing roughly $63 \%$ of all cigarette imports for Grenada. As Figure 1 indicates, in 2014 a 20-pack of the most-sold brand of cigarettes averaged, in Eastern Caribbean Dollars (EC\$) 8.37 or United States Dollars (US\$) 3.10.

Different scenarios were examined to determine a specified percentage decrease in product consumption, while monitoring changes in overall government revenues and excise revenues, among other variables. With elasticities ranging from -0.2 to -0.9 , the results show that to achieve a $5 \%$ fall in consumption, excise taxes would need to be increased by $17 \%$ to $117 \%$ of the CIF value, ${ }^{5}$ from a baseline of approximately $100 \%$ of CIF. The analysis also shows that total government revenues would grow by $8.7 \%$ (EC\$ 0.422 mil-

FIGURE 1. Selected brands of cigarettes sold in Grenada, by percent of market, 2014

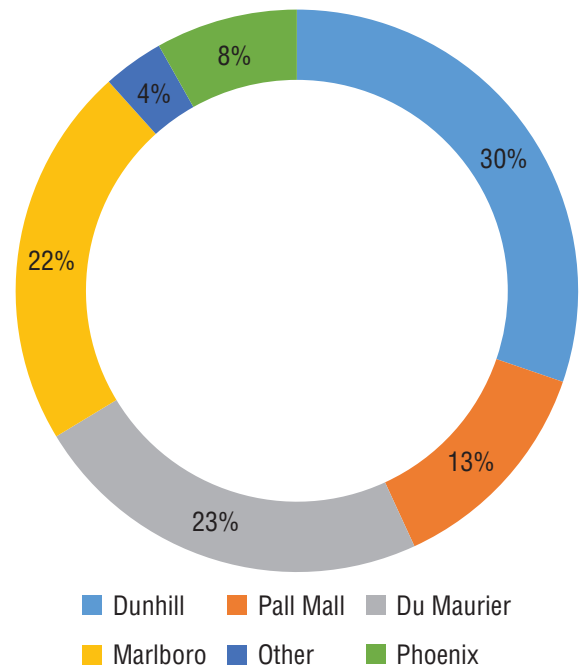

Source: Prepared by the authors from the study results

\footnotetext{
In practice, excise taxes are applied on a compounded base that includes import duties and customs service charge; however, for simplicity the equivalent CIF value was used.
}

lion/US\$ 0.156 million) and excise tax revenues would be expected to increase by $11 \%$ (EC\$ 0.40 million/US\$ 0.14 million), as a result. The average excise tax per pack of cigarettes would move from EC\$ 3.24 (US\$ 1.20) to EC\$ 3.80 (US\$ 1.41), a 17\% increase, while the average price per pack was predicted to increase to EC\$ 9.21 (US\$ 3.41) from its model baseline of EC $\$$ 8.48 (US\$ 3.14). ${ }^{6}$

In the $10 \%$ and $15 \%$ consumption reduction scenarios, excise taxes need to be increased to $133 \%$ (a 33\% increase) and $150 \%$ (a 50\% increase) of the CIF value, respectively, pushing the average excise tax per pack to EC\$ 4.37 (US\$ 1.62) and EC\$ 4.90 (US\$1.81), respectively. As a result, the average price per pack was forecasted to increase to EC\$ 9.98 (US\$ 3.70) and EC\$ 10.76 (US\$ 3.99), respectively. In the case of the $10 \%$ consumption reduction scenario, the changes in excise tax rate were also predicted to have a positive impact on total government revenues and excise tax receipts, likely of $16 \%$ (EC\$ 0.74 million/US\$ 0.27 million) and 21\% (EC\$ 0.79 million/US\$ 0.29 million), respectively. In the case of the $15 \%$ consumption reduction scenario, total government revenues and excise tax revenues were projected to rise by $23 \%$ and $29 \%$, respectively.

The results also show that in all cases, Grenada will move closer to the WHO-recommended excise tax burden of $70 \%$. Table 1 displays the details of the simulation results.

\section{DISCUSSION}

Based on the given tax rates and the assumed elasticities, there is some capacity to target the consumption of cigarettes without concern for loss of overall tax revenues in the short- and medium-term. The study shows that consumption can be reduced or controlled alongside increased government revenues. This result aligns with the general literature $(7,14,15)$ that shows taxation to be an effective means of pursuing the public health objective of reduced incidence of smoking-related illnesses via reduced consumption. Indeed, the most recently available data show that while smoking prevalence rates have been falling, the rate of change has been near negligible in some cases, ticking downward by 0.07 percentage points for women in 2015 (23). Meanwhile, tobacco-related deaths in 2016 remained relatively significant, an estimated $9.92 \%$ of all male deaths (24). This may be an indication that Grenada needs to escalate its tobacco control and prevention efforts if it is to make a meaningful dent in smoking rates and the consequential effects. Moreover, this predicted outcome signals that the fiscal authorities can create budgetary resources for health, with little immediate concern for any notable adverse effects to fiscal sustainability.

Limitations. Whereas the TaXSiM model offers a convenient method through which the effects of various tobacco taxation policies can be evaluated,

TABLE 1. TaXSiM results for Grenada, 2015 forecasts

\begin{tabular}{|c|c|c|c|c|c|c|c|}
\hline \multirow[t]{2}{*}{ Variables } & \multicolumn{7}{|c|}{ Consumption reduction scenarios } \\
\hline & Baseline & $5 \%$ & $\begin{array}{c}\text { Change } \\
\text { (\% change) }\end{array}$ & $10 \%$ & $\begin{array}{c}\text { Change } \\
\text { (\% change) }\end{array}$ & $15 \%$ & $\begin{array}{c}\text { Change } \\
\text { (\% change) }\end{array}$ \\
\hline Average price per pack of 20 (EC\$) & 8.5 & 9.2 & $0.7(8.6 \%)$ & 10.0 & $1.5(18.0 \%)$ & 10.8 & $2.3(27.0 \%)$ \\
\hline Average price per pack of 20 (US\$) & 3.1 & 3.4 & 0.3 & 3.7 & 0.6 & 4.0 & 0.9 \\
\hline Excise tax per pack 20s (EC\$) & 3.2 & 3.8 & $0.6(17.0 \%)$ & 4.4 & $1.2(35.0 \%)$ & 4.9 & $1.7(51.0 \%)$ \\
\hline Excise revenues (thousands, EC\$) & 3552 & 3947 & $395(11.1 \%)$ & 4296 & $744(20.9 \%)$ & 4593 & $1041(29.3 \%)$ \\
\hline Excise revenues (thousands, US\$) & 1316 & 1462 & 146 & 1591 & 276 & 1701 & 386 \\
\hline Total tax revenues (thousands, EC\$) & 4826 & 5248 & $422(8.7 \%)$ & 5616 & $790(16.4 \%)$ & 5925 & $1099(22.8 \%)$ \\
\hline Total tax revenues (thousands, US\$) & 1787 & 1944 & 156 & 2080 & 293 & 2194 & 407 \\
\hline $\begin{array}{l}\text { Average excise tax burden (excise } \\
\quad \text { tax as } \% \text { of price) }\end{array}$ & $38.3 \%$ & $41.2 \%$ & 0.03 & $43.8 \%$ & 0.1 & $46.0 \%$ & 0.1 \\
\hline $\begin{array}{l}\text { Average tax burden (total tax - } \\
\text { import, excise, and VAT - as \% } \\
\text { of price) }\end{array}$ & $52.0 \%$ & $54.8 \%$ & $2.8 \%$ & $57.2 \%$ & $5.2 \%$ & $59.3 \%$ & $7.3 \%$ \\
\hline
\end{tabular}

Source: Produced by the authors from the study data.

\footnotetext{
The model overestimates the price per pack by ECS 0.11 or $1.31 \%$. This error falls within the statistically acceptable range.
} 
limitations to this approach do exist. One limitation of the model is that it is unable to predict the response of the tobacco industry to various tobacco taxation policies. Additionally, the model is unable to comprehensively account for the illicit consumption that may occur in response to the higher cigarette price. Furthermore, while the model assumes the existence of a segmented cigarette market, it is possible that such segmentation may not explicitly exist. However, pricing data and retailer feedback indicate that these segments do exist in the Grenada market.

\section{Conclusions}

The levying of a special tax on tobacco appears to be a viable option for the cre- ation of additional fiscal space for health and social programs; in particular, to create and enhance already existing addiction treatment and prevention programs. This will align with the Government of Grenada's general anti-drug and anti-addiction programs, especially targeting the country's youth. In addition, the predicted increases in government revenues will provide an opportunity for improved social conditions for the general population. The determining factor is how well these additional monetary resources will be used.

Furthermore, the simulations indicate that in addition to the supplementary fiscal resources predicted, the application of higher taxes to tobacco products will likely lead to a reduction in tobacco use in Grenada. The ultimate result of this will be reduced tobacco-related NCD mortality and morbidity. In addition, whereas this study was conducted in Grenada, the results are likely to be mirrored in other CARICOM Member States, considering the social and economic similarities.

Acknowledgements. The authors wish to thank Ms. Rani Bhajan for her role in the study.

Conflict of interests: None declared.

Disclaimer. Authors hold sole responsibility for the views expressed in the manuscript, which may not necessarily reflect the opinion or policy of the RPSP/ PAJPH and/or PAHO.

\section{REFERENCES}

1. World Health Organization. Tobacco: key facts. 2018. Available from: http:/ / www. who.int/news-room/fact-sheets / detail/tobacco Accessed 6 July 2018.

2. The World Bank. Country and Lending Groups. Available from: https://datahelpdesk.worldbank.org/knowledgebase/articles/906519-world-bank-country-andlending-groups Accessed 29 October 2018.

3. Central Intelligence Agency. The World Factbook: Central America and the Caribbean: Grenada. Available from: https:// www.cia.gov/library/publications / the-world-factbook/geos/gj.html Accessed 2 April 2018.

4. United Nations. UN comtrade: international trade statistics. Available from: https://comtrade.un.org/data/ Accessed 2 July 2018

5. International Trade Centre. Trade map: trade statistics for international business development. Available from: https:// www.trademap.org/Index.aspx Accessed 2 July 2018.

6. Customs \& Excise Division, Grenada. Available from: https://www.gov.gd/ departments/customs_division.html Accessed 2 November 2018.

7. World Health Organization. Framework Convention on Tobacco Control. Geneva; WHO; 2003. Pp. 42. Available from: http:// www.who.int / tobacco/framework/ WHO_FCTC_english.pdf Accessed 8 July 2018.

8. Van Walbeek C. The economics of tobacco control in Jamaica: will the pursuit of public health place a fiscal burden on the government? 2005. Available from: http://www.tobaccoecon.uct.ac.za/ sites/default/files/image_tool/ images / 405/Publications/reports / TheEconomics-of-Tobacco-Control-in-Jamaica.-Will-the-Pursuit-of-Public-Healthplace-a-Fiscal-Burden-on-the-Government.pdf Accessed 18 October 2018.

9. Duffy M. The demand for alcoholic drink in the United Kingdom, 1963-78. Appl Econ. 1983;15:125-40. Available from: http:/ / www.tandfonline.com/doi/pdf/ 10.1080/00036848300000059 Accessed 19 October 2018.

10. Chaloupka F. Rational addictive behavior and cigarette smoking. National Bureau of Economic Research. 1990. Available from: http: / / www.nber.org/papers / w3268 Accessed 19 October 2018.

11. Baltagi B, Levin D. Estimating dynamic demand for cigarettes using panel data: the effects of bootlegging, taxation and advertising reconsidered. Rev Econ Stat. 1986;68(1):148-55. Available from: http:/ / www.jstor.org/stable/1924938 Accessed 19 October 2018.

12. $\mathrm{Hu} \mathrm{T}$, Mao Z. Economic analysis of tobacco and options for tobacco control: China case study. Tob Control. 2002. Available from: https://escholarship. org/uc/item/5x2015sv Accessed 19 October 2018.

13. Cordes JJ, Nicholson EM, Sammartino FJ. Raising revenue by taxing activities with social costs. Natl Tax J. 1990;43(3):343-56. Available from: http://search.ebscohost. com $/$ login. aspx?direct $=$ true $\& d b=b$ th $\&-$ AN=9706062167\&site=ehost-live Accessed 19 April 2017.

14. Perucic AM. The demand for cigarettes and other tobacco products. In: TobTaxy Capacity Building Workshop, 20-22 February 2012. Dublin: World Health Organization; 2012. Pp. 34. Available from: http: / www.who.int/tobacco/ economics/meetings/dublin_demand_ for_tob_feb2012.pdf Accessed 19 October 2018.

15. Ahsan A, Wiyono NH, Kiting AS, Djutaharta T, Aninditya F. Impact of increasing tobacco tax on government revenue and tobacco consumption. SEADI Discussion Paper Series. 2013. Pp. 55. Available from: https://www.researchgate.net/publication / 280483053_Impact_of_Increasing_Tobacco_Tax_on_ Government_Revenue_and_Tobacco_ Consumption Accessed 2 November 2018.

16. Van Walbeek C. A simulation model to predict the fiscal and public health impact of a change in cigarette excise taxes. Tob Control. 2010;19(1):31-6. Available from: http: / / www.ncbi.nlm.nih.gov / pubmed/19850550 Accessed 19 October 2018.

17. Howard M, La Foucade A, Scott E. Public sector economics for developing countries. $2^{\text {nd }}$ ed. Kingston: University of the Indies Press; 2009.

18. Yurekli A, Bayer J de. Design and administer tobacco taxes. World Bank, Econ Tob Toolkit. 2001;(202). Available from: http://virtual.usergioarboleda.edu. co/file.php/978/Documentos_clave / Taxes_Banco_Mundial.pdf Accessed 8 December 2014.

19. International Center for Alcohol Policies. Alcohol taxation. Washington, DC: ICAP; 2006.

20. Elder R, Lawrence B, Ferguson A. The effectiveness of tax policy interventions for reducing excessive alcohol consumption and related harms. Am J Prev Med. 2009;38(2):217-29. 
https: / / doi.org/10.1016/j.amepre. 2009.11.005 Accessed 19 October 2018.

21. World Health Organization. The World Health Organization's Tobacco Tax Simulation Model (WHO TaXSiM). Geneva: WHO; 2013.

22. World Health Organization. WHO report on the global tobacco epidemic, 2017: monitoring tobacco use and prevention policies. Geneva: WHO; 2017.

23. American Cancer Society, Vital Strategies. Drop J, Schluger NW, eds. The tobacco atlas. Atlanta: ACS, Vital Strategies; 2018. Pp. 58. Available from: https://tobaccoatlas.org/wp-content/ uploads/2018/03/TobaccoAtlas_
6thEdition_LoRes_Rev0318.pdf Accessed 19 October 2018.

Manuscript received on 2 February 2018. Accepted for publication on 11 October 2018.
RESUMEN

\section{Aumento de los impuestos a los cigarrillos en Granada: efectos potenciales sobre el consumo y los ingresos públicos}

Palabras clave
Objetivo. Investigar la viabilidad de abordar los problemas de salud pública relacionados con el consumo de tabaco mediante un aumento de los impuestos, al tiempo que se conservan o aumentan los ingresos públicos del gobierno en Granada.

Métodos. Se utilizaron métodos de muestreo intencional para garantizar la disponibilidad de datos y su representatividad geográfica. Se calculó el precio promedio del paquete de 20 cigarrillos de las marcas más vendidas a partir de los datos obtenidos en tres grandes supermercados. Se utilizó el Modelo de Simulación de Impuestos de la Organización Mundial de la Salud, con tasas de impuestos al consumo ajustadas para obtener reducciones del 5\%, 10\% y 15\% en el consumo.

Resultados. Un aumento del $17 \%$ al $117 \%$ en el impuesto al consumo sobre el valor del costo, seguro y flete (CSF) ocasionaría una disminución del $5 \%$ en el consumo. Los ingresos totales del gobierno crecerían un 8,7\% y los ingresos por impuesto al consumo aumentarían un $11 \%$. El impuesto al consumo promedio por paquete de 20 cigarrillos aumentaría de EC \$ (dólar del Caribe oriental) 3,24 (USD 1,20 de 2014) a EC\$ 3,80 (USD 1,41), y el precio promedio por paquete aumentaría de EC $\$ 8,48$ (USD 3,14) a EC $\$ 9,21$ (USD 3,41). En los escenarios de reducción del consumo del 10\% y el 15\%, los impuestos al consumo deberían aumentarse en un 33\% y 50\% (al 133\% y 150\% del $\mathrm{CSF}$, respectivamente), lo que elevaría el promedio del impuesto al consumo por paquete a EC \$ 4,37 (USD 1,62) y EC \$ 4,90 (USD 1,81), respectivamente.

Conclusión. En Granada, el consumo de tabaco puede reducirse y aumentarse a la vez los ingresos públicos, generando recursos adicionales disponibles para la salud. Esto coincide con la bibliografía publicada, que indica que los impuestos pueden ser eficaces para alcanzar el objetivo de salud pública de reducir la incidencia de enfermedades relacionadas con el hábito de fumar a través de una reducción del consumo.

Tributación de los productos derivados del tabaco; legislación como asunto; enfermedades no transmisibles, prevención \& control; Grenada; Región del Caribe. 
RESUMO Objetivo. Investigar a viabilidade de abordar problemas de saúde pública relacionados ao consumo de tabaco através de um aumento de impostos, enquanto conserva ou aumenta a receita do governo em Granada.

Métodos. Métodos intencionais de amostragem foram utilizados para garantir a disponibilidade de dados e sua representatividade geográfica. O preço médio da embala-

Aumento Dos Impostos Sobre Os Cigarros Em Granada: Efeitos Potenciais Sobre O Consumo E As Receitas Públicas

Palavras-chave gem de 20 cigarros das marcas mais vendidas foi calculado a partir dos dados obtidos em três grandes supermercados. Utilizou-se o Modelo de Simulação Tributária da Organização Mundial de Saúde, com taxas de imposto de consumo ajustadas para obter reduções de $5 \%, 10 \%$ e $15 \%$ no consumo.

Resultados. Um aumento de $17 \%$ para $117 \%$ na taxa de consumo sobre o valor do custo, seguro e frete (CSF) causaria uma queda de 5\% no consumo. As receitas totais do governo aumentariam em $8,7 \%$ e as receitas dos impostos sobre o consumo aumentariam em $11 \%$. O imposto médio de consumo por pacote de 20 cigarros aumentaria de EC \$ (dólar do Caribe Oriental) 3,24 (USD 1,20 de 2014) para EC \$ 3,80 (USD 1,41), e o preço médio por pacote aumentaria de EC \$ 8,48 (USD 3,14) para EC\$ 9,21 (USD 3,41). Nos cenários de redução do consumo de $10 \%$ e 15\%, os impostos sobre consumo devem ser aumentados em 33\% e 50\% (para 133\% e 150\% do CSF, respectivamente), o que elevaria a média do imposto sobre o consumo por pacote a EC \$ 4,37 (USD 1,62) e EC\$ 4,90 (USD 1,81), respectivamente.

Conclusão. Em Granada, o consumo de tabaco pode ser reduzido e as receitas do governo aumentadas, gerando recursos adicionais disponíveis para a saúde. Isso coincide com a literatura publicada, que indica que os impostos podem ser efetivos para alcançar o objetivo de saúde pública de reduzir a incidência de doenças relacionadas ao tabagismo através da redução do consumo.

Tributação sobre os produtos derivados do tabaco; legislação como assunto; doenças não transmissíveis, prevenção \& controle; Granada; Região do Caribe. 